UDC 371.124:377.112.4

Maksymenko Tetyana

Sumy State Pedagogical University

named after A. S. Makarenko

ORCID ID 0000-0002-8863-5603

Yana Glyva

Sumy State Pedagogical University

named after A. S. Makarenko

ORCID ID 0000-0002-7605-5580

Anastasiya Alexandrova

Sumy State Pedagogical University

named after A. S. Makarenko

ORCID ID 0000-0003-3705-2202

DOI 10.24139/2312-5993/2020.05-06/096-105

\title{
SOCIAL COM PETENCE IN THE PROFESSIONAL COM PETENCE STRUCTURE OF THE FUTURE TEACHER OF THE HIGHER EDUCATION INSTITUTION
}

The article highlights position of the authors on the place of future teacher's competence in the professional competence structure. The scientific approaches to the determination of the notions "competence" and "competences" are presented. The authors' definition of the concept essence of future teacher's social competence is offered. The structural analysis of social competence is carried out and its components are defined. The importance of partnership cooperation of the future teacher for creation of favorable conditions for training and education in the higher educational institution is substantiated. The realization ways of social competence of the future teacher in the structure of professional competence are highlighted.

Key words competence, social competence, professional competence, future teacher, institution of higher education.

Introduction. In the conditions of progressive changes in the society, the significance of education radically changes, the idea of the content and role of social competence in the structure of the future teacher's professional competence in the higher education institution expands. Also relevant is the problem of professional competence, the specifics of which we can see in scientific and pedagogical research and regulatory requirements for the future teacher of the higher education institution and his/her social competence in the structure of professional competence.

Ukrainian socio-economic conditions determine the need for advanced development of the educational sector, modernization of higher education, which, in turn, involves increasing the future teachers' competence at all levels. Naturally, the innovative transformations nature in education requires the 
improvement of teachers' professionalism, readiness for continuous professional growth, active work at the level of world standards. A special place in this process is occupied by the teacher's social competence as an integral professional and personal characteristics, which allows carrying out effectively professional activities in the new organizational and pedagogical conditions.

Analysis of relevant research. The concept of "professional competence" was studied by such scientists as E. Andriienko, O. Asmolov, O. Kovalenko, D. Kozlov, I. Nazarova, V. Petruk, V. Slastionin, and others. The problem of analysis and development of the modern specialist's professional competence and its components are considered in the works of many domestic and foreign researchers: V. Baidenko, I. Yermakova, I. Zymnia, O. Ovcharuk, A. Petrova, 0. Pometun, J. Ravenna, A. Khutorskyi and others.

Issues of social competence have only recently become the subject of special consideration. In modern psychological and pedagogical discourse there is a growing interest of scientists in various aspects of social competence (V. Basov, S. Bakhtieieva, D. Vorontsov, L. Kalinin, V. Kunitsyn and others). In the pedagogical and psychological literature the process of social competence formation is studied in relation to student youth (S. Bakhtieieva, E. Kazakov, O. Kolobova, N. Lupanova, L. M ytina, L. Shabatura and others).

Despite the fact that the number of publications on the implementation of the competence approach in education is constantly growing, the content of the higher education institution teacher's professional competence hasn't received relevant attention.

The aim of the article: to find out the essence of the social competence concept in the professional competence structure of the future teacher of the higher education institution; to reveal the content of each indicated component of the future teacher's social competence; to identify structural components of the future higher education institution teacher's social competence.

In order to achieve the aim the following research methods have been used: analysis, synthesis, comparison, generalization, concretization, classification, systematization - to study the essence of the social competence concept in the structure of the future teacher's professional competence.

Research results. Modernization of education today is aimed at training not only a highly qualified specialist according to the demand of the labor market, but also a person who is ready to change rapidly in different situations and make the right decisions, able to solve problems in various fields and activities based on social experience, an element of which is their own experience. 
The educational process organization is aimed at creating conditions for the formation of the future teacher's experience of independent decision-making on the cognitive, communicative, organizational, moral and other problems that make up the education content. At the same time, the actual education content is a didactically adapted social experience of solving such problems. These provisions are fundamental in the competence approach in education.

The concept of "social competence" was introduced into scientific circulation by the German scientist G. Roth, who considered social competence to be one of the types of human competence that reflects interaction between people (Mosiagina, 2008). M. Lukianova considers social competence as a personal formation and interprets this phenomenon as "a conscious expression of the personality, which is manifested in his/her beliefs, views, attitudes, motives to certain behavior, in the personal qualities formation that promote constructive interaction" (Golovan, 2014). According to M. Doktorovych, "social competence" is a complex intertwining of skills, knowledge and actions, oriented and organized in accordance with the surrounding social reality, which open and provide the possibility of self-realization in a given system (Doktorovych, 2009).

Social competence can be manifested in abilities of different levels starting with elementary communication (for example, eyesight contact), social perception abilities (such as understanding and interpreting social signals), specific behaviors, ways of interactions (for example, active listening, mutual communication, ignorance, etc.), which are applied by the individual when performing a social task; and finishing with communication skills - i.e. effectively interact with others, adequately react, avoiding interpersonal conflicts, adapt to both simple, and complex situations (Matson et al., 2008). L. K. Elksnin and N. Elksnin (2000) and others are of a similar opinion: social skills manifest in learnt verbal and nonverbal (posture, eye contact, intonation, mimic) communication manners and abilities of sharing (M orrison et al., 2001), initiation of interactions (Heimann et al., 1995).

R. M. Rapee et al. (2000) concern social skills that come into play in nonverbal and verbal communication manners: body language - eye contact, posture, mimic; voice-quality - tone and altitude of voice, speech pace, clarity and interaction abilities: conversation - greeting, introducing oneself, initiation of conversations; expression of favor, benevolence, friendship - offering help, invitation, asking to join, expression of gentleness, complementing the other, sympathy, when others are hurt or sad; assertiveness - protection of one's rights, asking for help or information, expressing one's needs, refusal, coping with annoyance, harassment, etc. J. Zins et al. (2004) distinguish the following 
components in the structure of social competence: social comprehension skills (understanding and interpreting social factors), social behavior skills (creation of positive relations, responsible decision-making; constructive and ethical management of difficult situations), and emotion management skills (recognition and control of emotions; sympathy and care for others).

Thus, for a successful professional activity the future teacher needs a fairly stable and adequately high self-esteem, a positive view of the world, the ability to manage one's emotional state, self-confidence. He must show empathic abilities in relation to another person, be able to respond adequately in conflict situations.

Note that these qualities, according to V. Kunitsyna, are part of the structure of social competence (Kunitsyna, 1995). Social competence in the hierarchy of competences occupies a leading place and can be determined in the same way as the person's ability and willingness to regulate his/her own relationships with the surrounding reality and other people.

V. Kunitsyna proposed the following social competence definition: "Social competence is a system of knowledge about social reality and about oneself, a system of complex social skills and interaction skills, behavioral scenarios in typical social situations that allow to quickly and adequately adapt, make informed decisions (Kunitsyna, 1995).

Social competence is considered by many authors as a personal formation (Doktorovich, 2009). In this case, it includes:

- awareness of the need to adopt the particular society norms;

- the desire to understand its essence;

- awareness of the need to expand existing social skills in connection with changes in the current situation;

- willingness to take personal responsibility for their own choice of a certain course of action in a situation of social interaction;

- social experience based on the principles of constructive communication.

According to I. Frumin, formation of such competence will indicate cognitive readiness, patterns of action that are accepted and approved by all, which indicate the ability of the individual to solve his/her own problems and the partners' problems (Frumin, 2003).

Thus, social competence is attributed the ability to communicate, cooperate, resolve conflicts, achieve the goal, easily adapt, show personal initiative, take responsibility. 
The content of each indicated social competence components V. Kunitsina discloses as follows (Kunitsyna, 1995):

- operational social competence - knowledge of social institutions and structures, their representatives in society; ideas about functioning of social groups, about the current situation, about the breadth and originality of the requirements for the repertoire of the role behavior; measured by general social orientation and awareness;

- verbal competence - the statements appropriateness, taking into account their context and subtext, lack of difficulties in written language, variability of interpretation of information, good orientation in the field of evaluative stereotypes and patterns, plurality of meanings in the use of concepts, metaphorical language; an example of verbal competence is the translator's activity, who simultaneously translates oral language, when you need a quick and adequate understanding of statements and finding the exact equivalent in the literal and contextual meaning of words and concepts, examples of verbal incompetence may be inappropriate use of proverbs, sayings in the new social or context;

- communicative competence - possession of complex communication skills; formation of adequate skills in new social structures; knowledge of cultural norms and restrictions in society; knowledge of customs, traditions, etiquette in the field of communication, compliance with the rules of decency, politeness; orientation in the means of communication inherent in the national, class mentality and expressing development of the role repertoire in this profession;

- socio-psychological competence - interpersonal orientation, ideas about the diversity of social roles and ways of interaction; ability to solve interpersonal problems; developed scenarios of behavior in complex conflict situations;

- ego-competence - awareness of one's nationality, gender, caste, group affiliation, knowledge of one's strengths and weaknesses, capabilities and resources, understanding the causes of one's mistakes, knowledge of selfregulation mechanisms and the ability to use them, psychological knowledge about oneself, acquired in life experience.

Social competence can also be seen as knowledge of social objects, trends and their changes, the rules of relations regulation in social reality through the value-normative system that has developed in certain communities.

The structural components of social competence include (Mosyagina, 2008): 
- motivational-value - formation of motivation for the achievement pursuit, attitude to social interaction, the nature of the public and personal order values, attitude to moral norms existing in this society;

- operational-content - the amount and nature of knowledge, skills and abilities, which allows for critical analysis of one's own and others' actions, predict their consequences, communicate, etc.

- emotional and volitional - the ability to choose a decision, self-control and self-regulation, willingness to take responsibility, determination to act.

Social competence, according to $\mathrm{M}$. Golovan, is an integrated personal formation, which combines a valuable understanding of social reality, categorical specific social knowledge, acting as a guide to action, the subjective ability to self-determination, personal ability to implement social technologies in the main areas of human activity (Golovan, 2014).

It is believed that in the social competence structure of the future teacher the actual components can be distinguished:

- cognitive - development of social meanings, values, norms;

- emotional and volitional - acceptance and volitional readiness of the future teacher to follow social meanings, values, norms;

- activity - productive activity perceived by the future teacher as a social significant event, effective interpersonal interaction.

Researchers of social competence identify the following three components of its structure:

1. Component associated with goal-setting: the ability to take on responsibility, participate in decision-making, put goal and plan the result, analyze and correct.

2. Component related to orientation to the other: skills of understanding and accommodating others feelings and needs, managing one's emotions in communication.

3. Component related to social mobility and human activity: the study of the environment for identifying its capabilities and resources, willingness to use new ideas to achieve the goal.

Formation of the social competence of the future teacher as a whole is influenced by the following factors:

- motivation of the professional activity of the future teacher;

- individual psychological characteristics of the individual;

- personal self-esteem.

For the formation of social competence of the teacher, an appropriate educational process is required. Social relationships in progress teaching that 
can be called social-didactic must correspond, be consistent, associated with professional social relations of the teacher (M osiagina, 2008).

A system-forming factor that determines the purposeful formation and functioning of social competence elements is the student's activity. The educational process of future teachers preparation should be communicative, activity-based, interactive. In general, such process can be called social competence formation at the higher education institution.

The basic provisions of the theoretical study of the development of ideas for the formation of social competence G. M osiagina formulated as follows.

First, social competence is a complex phenomenon that is considered at the junction of a complex of social and psychological-pedagogical sciences, which is part of the personality's competence as a whole, the basis of its success.

Second, the purpose of social competence formation in the broad sense is development of human relations to the world: M otherland, society, people, animate and inanimate nature, material and spiritual values, to oneself, i.e. formation of life position - one's place in the system of value relations to the world. At the same time, the attitude is an electoral category, so in the process of personality's social competence formation it is placed in a situation of choosing political, economic, moral, aesthetic values, in the position of an active subject of the activity process and self-development.

Third, to consider the optimal process of social competence formation, it is necessary to study the following factors: socio-cultural environment, family, team, informal associations. When studying the socio-cultural environment, its pedagogical potential is important; when studying the family - the moral and psychological climate; when studying the team - the psychological climate, social status in the group, the openness of the team; in the study of informal associations - social activity, positive social orientation, positive attitude to the traditions formed in the team.

Fourth, the most important conditions that contribute to the formation of social competence in an education institution are its transformation into an open socio-pedagogical system, a teachers' high professional level, a favorable psychological climate in the education institution.

Fifth, in the study of social competence itself, it is important to study the important components: health (physical development indicators, the health culture mastery); training (mastering key competences level, motivation level to study, self-organization level of educational activities, etc.); development (life values characteristics, openness, sociability, tolerance, self-esteem, internal potential realization, civic qualities, moral qualities, ideas about life 
goals, ideas about possible choice of profession, etc.); education (development level of self-organization and self-discipline, focus on socially acceptable norms of behavior, etc.); social stability (level of social adaptation and socialization, social mobility and activity).

The question of the formation of the future student's social competence is a question of their preparation for independent life, their social protection and social formation.

Conclusions and prospects for further research. So, summarizing the different points, according to the authors, the key concept of "social competence" in the context of the teachers' professional profile is an integrative professional and personal quality, which is a structured system of interconnected knowledge, skills and abilities; activity ways that are set in relation to the psychological and pedagogical activities in the education institution, which determine the teacher's ability and willingness to establish contacts with the subjects of the educational process; participate in joint decision-making and conflict resolution through non-violent means. Based on this definition, the main characteristics of the social competence for the future teacher personality are developed social intelligence and empathy for others, reflexive abilities, the ability to behave productively in conflict situations.

Literature review also allows to conclude that formation of social competence in vocational education is especially relevant.

However, during this period the person receives professional and humanitarian knowledge, professional, personal and cultural training. Secondly, in this age period the process of intensive worldview search of the main life values is carried out.

Further studies will be directed at revealing positive conceptual ideas of the future teacher's social competence formation at the higher education institution.

\section{REFERENCES}

Горохівська, Т. М. (2019). Проблема визначення структури професійно-педагогічної компетентності викладачів закладів вищої освіти у працях вітчизняних науковців. Педагогіка формування творчої особистості у вищій $і$ загальноосвітній школах, $62, \quad 2 . \quad$ Режим доступу: http://pedagogyjournal.kpu.zp.ua/archive/2019/62/part_2/11.pdf (Horokhivska, T. M. (2019). The problem of determining the structure of teachers' professional and pedagogical competence of higher education institutions in the works of domestic scientists. Pedagogy of creative personality formation in higher and general education schools, 62, $2 . \quad$ Retrieved from: http://pedagogyjournal.kpu.zp.ua/archive/2019/62/part_2/11.pdf).

Куницина, В. Н. (1995). Социальная компетентность и социальный интеллект: структура, функции, взаимоотношения. Теоретические и прикладные вопросы психологии, 1, 
48-61 (Kunitsyna, V. N. (1995). Social competence and social intelligence: structure, functions, relationships. Theoretical and applied issues of psychology, 1, 48-61).

Мосягина, Г.П. (2008). Формирование социальной компетенции будущих педагогов (на примере педагогического колледжа) (автореф. дис. ... канд. пед. наук: 13.00.08). Астрахань (M osiagina, G. P. (2008). Formation of future teachers' social competence (on an example of pedagogical college) (thesis abstract: 13.00.08). Astrakhan).

Doktorovych, M. O. (2009). Social competence as a scientific problem. Psychology and society, 3, 144-147.

Elksnin, L. K., Elksnin, N. (2000). Teaching parents to teach their children to be prosocial. Intervention in School and Clinic, 36 (1), 27-35.

Frumin, I. D. (2003). Competence approach as a natural stage of updating the education content. Development pedagogy: key competencies and their formation: Proceedings of the 9th scientific-practical conference. Krasnoyarsk: Krasnoyarsk. state un-ty, pp. 33-56.

Golovan, M. S. (2014). The teacher's professional competence of the higher educational institution. Problems of modern pedagogical education. Series: Pedagogy and psychology. Collection of articles, 44 (3), 79-88.

Heimann, M., Nelson, K., Tjus, T., Gillberg, C. (1995). Increasing reading and communication skills in children with autism through an interactive multimedia computer program. Autism Development Disorders, 25, 459-480.

Lukianova, I. I. (2001). Basic needs for the development of adolescents' social competence. Psychological science and education, 4, 41-47.

Matson, J. L., Cooper, C., Malone, C. J., Moskow, S. L. (2008). The relationship of self-injurious behavior and other maladaptive behaviors among individuals with severe and profound intellectual disability. Research in Developmental Disabilities, 29 (2), 141-148.

Morrison, L., Kamps, D., Garcia, J., Parker, D. (2001). Peer mediation and monitoring strategies to improve initiations and social skills for students with autism. Positive Behavior Interventions, 3 (4), 237-250.

Rapee, R. M., Wignall, A., Hudson, J. L., Schniering, C. A. (2000). Treating Anxiety in Children and Adolescents: An Evidence-Based Approach. California: New Harbinger.

Skirko, R. L. (2010). Formation of social competence of future practical psychologists in the professional training process (thesis abstract). Zaporizhzhia.

Zns, J., Weissbert, R., Wang, M., Walberg, H. (2004). Building Academic Success on Social and Emotional Learning: What doe the Research Say? New York: Teachers College Press.

\section{PEЗЮME}

Максименко Татьяна, Глива Яна, Александрова Анастасия. Соціальна компетентність у структурі професійної компетентності майбутнього педагога закладу вищої освіти.

Стаття розкриває позицію авторів щодо місця компетентності майбутнього педагога у структурі професійної компетентності. у статті здійснено теоретичне узагальнення стану дослідження представленої проблеми в науковій літературі. Розглянуто наукові підходи до визначення понять «компетентність» та «компетенція».

Розкрито підходи до трактування визначення складових понять «сочіальна компетентність». Запропоновано авторське визначення сутності поняття соціальної компетентності майбутнього педагога. Соціальна компетентність 
особистості є інтегрованою соціальною якістю особистості, що включає ціннісне розуміння соціальної дійсності, конкретне соціальне знання як керівництво до дії, суб'єктну здатність до самовизначення, самоврядування та нормотворчості; уміння здійснювати соціальні технології в головних сферах життєдіяльності (у системі соціальних інститутів, норм і відносин) згідно з належним рівнем культури, моральності і права.

У статті розглянуто сутність професійної та соціальної компетентності в структурі профресійної компетентності майбутнього педагога в закладі вищої освіти. Склад і зміст компетентностей викладача закладу вищої освіти визначено відповідно до положень компетентнісного підходу, вимогами до претендентів на посаду викладача закладу вищої освіти, а також на основі кваліфрікаційних характеристик посад професорсько-викладацького складу зВО.

Здійснено структурний аналіз соціальної компетентності й визначено ії компоненти. Обгрунтовано значимість партнерської співпраці майбутнього педагога для створення сприятливих умов для навчання та виховання в закладі вищої освіти. Висвітлено шляхи реалізації соціальної компетентності майбутнього педагога у структурі профресійної компетентності.

Розкрито зміст кожної з означених складових соціальної компетентності майбутнього педагога закладу вищої освіти. Виокремлено структурні компоненти соціальної компетентності майбутнього педагога в закладі вищої освіти.

Ключові слова: соціальна компетентність, компетентність, професійна компетентність, майбутній педагог, заклад вищої освіти.

\section{PEЗЮME}

Максименко Татьяна, Глыва Яна, Александрова Анастасия. Социальная компетентность в структуре профессиональной компетентности будущего педагога учреждения высшего образования.

В статье освещены позиции авторов о месте компетентности будущего педагога в структуре профессиональной компетентности. $B$ статье сделано теоретическое обобщение состояния исследования представленной проблемы в научной литературе. Рассмотрены отдельные научные подходы к определению понятий «компетентность» и «компетенция». Рассмотрена сущность профрессиональной компетентности и социальной компетентности в структуре профрессиональной компетентности будущего педагога в учреждении высшего образования. Состав и содержание компетентностей преподавателя высшего учебного заведения определены в соответствии с положениями компетентностного подхода, требованиями к претендентам на должность преподавателя учреждения высшего образования, а также на основе квалификационных характеристик должностей профессорско-преподавательского состава ЗВО.

Ключевые слова: социальная компетентность, компетентность, профрессиональная компетентность, будущий педагог, учреждение высшего образования. 